\title{
Tax Administration and Entrepreneurial Performance: A Study of SMEs in Uganda
}

\author{
Ismail Kintu $^{1}$, Faisal Buyinza ${ }^{2} \&$ Yusuf Kiwala ${ }^{1}$ \\ ${ }^{1,}$ School of Business, College of Business and Management Sciences, Makerere University, Kampala \\ ${ }^{2}$ School of Economics, College of Business and Management Sciences, Makerere University, Kampala \\ Correspondence: Ismail Kintu, School of Business, College of Business and Management Sciences, Makerere \\ University, Kampala.
}

Received: June 28, 2019

Accepted: August 21, 2019

Online Published: November 8, 2019

doi:10.5539/ibr.v12n12p39

URL: https://doi.org/10.5539/ibr.v12n12p39

\begin{abstract}
Using the 2013 World Bank Enterprise Survey Data for Uganda, this paper employs the logit and quintile estimation technique to explain the relationship between tax administration and entrepreneurial performance among SMEs in Uganda. The study also employed interviews to obtain expert opinion about tax administration and also explain the results of logit models. Our results indicate that tax rate positively and significantly affect entrepreneurial performance, while tax administration has no effect on entrepreneurial performance. Other key factors that promote entrepreneurial performance include access to credit, firm age, male ownership, training and participation in exporting. Our results suggest that efforts to incentivize and set a conducive tax rate, ease of access to financing and training need to be strengthened for higher entrepreneurial performance among SMEs in Uganda.
\end{abstract}

Keywords: tax administration, SME performance, Uganda

\section{Introduction}

\subsection{Problem Introduction}

Tax administration is vital for economic performance in both government revenue collection and business performance (Godin \& Hindriks, 2015; Kangave, Nakato, Waiswa \& Zzimbe, 2016). Tax administration in Uganda has gradually improved from manual forms to electronic system where tax payers need to access tax information at their convenience and consult on tax matters 24 hours using the toll free line. Furthermore, URA opened up a number of fora for tax education and sensitization for instance; URA launched 'Ask URA' mobile application with Mobile Telephone Network Company (MTN), URA conducts workshops and seminars to vendors and landlords (Uganda Revenue Authority Annual Report, 2015/2016). The efforts are in the spirit of improving tax compliance with minimum cost to the tax payer. It can be argued that once the compliance cost in terms of efforts, time and monetary losses to SMEs are minimized, the resources saved may be utilized by SMEs for market penetration hence increased sales or financing working capital or any other SME activity.

Despite the fact that URA has endeavored to administratively simplify the tax system, the cost of compliance is still a problem to SMEs. Some SME entrepreneurs are illiterate, therefore, they need to hire tax consultants to help them file returns and interpret trade laws and regulations especially for custom purposes. Besides hiring tax consultants, the internet supply in Uganda is not reliable, or in other cases the cost of internet adds extra burden to SME operators. Furthermore, despite the numerous complaints made by traders about delayed administrative feedback (Kato, 2017) especially in clearing imports at various customs points, URA has not yet established a proper solution. In addition, taxes such as Value Added Tax (VAT) require filing monthly returns, this alone may be cumbersome to SMEs because of the costs of filing returns and the implications if the tax payer defaults. Therefore, there is high compliance encumbrance which tends to divert SMEs resources from entrepreneurial performance. It has not yet been established in Uganda's context whether the wasted time (delayed feedback and delay in understanding customs regulations and procedures) and money while endeavoring to comply for tax can impact on SME innovations, working capital, sales volume and market share. In other words, it is not yet clear whether tax administration can be an obstacle to SMEs' performance in Uganda, and to what extent it can be. However, in South Africa's construction industry, a study by Matarirano, Chiloane-Tsoke and Makina (2019) 
established that, while internal tax compliance costs (such as; employing extra personnel to handle filing of returns, time and procedure to understanding the compliance procedure and issuing of invoices) are positive and significantly related to firm performance, the external tax compliance costs (such as; hiring professional accounting firms, clearing agents and buying internet services) are negative and significantly related to firm performance. And, whereas the Matarirano et al; (2019) study was about the construction sector, the World Bank Enterprise survey (2013) where secondary data was obtained for analysis was not limited in scope. The survey considered both manufacturing and service sector firms in Uganda.

This study set out to investigate the relationship between tax administration (as an obstacle or not obstacle) and tax rates on firm performance taking into consideration other firm and entrepreneurial characteristics and the business environment. The firm performance measures were discussed by Yu (2013) and Bosma, Van Praag and Wit (2002). The same measures were tested in Uganda's informal economy by Kintu (2017).

Despite the improvements made by URA to ensure convenient and cost effective tax administration, there are still aspects of delayed decision making by revenue officers and bureaucratic tendencies (Kato, 2017). These tax administrative challenges may affect performance of SMEs in terms of time wastage or cash flow stagnation in case a decision requires monetary compensation or release of trader's goods for the market. This may impact on entrepreneurial performance. Moreover, there is relative research paucity about tax administration and entrepreneurial performance in Uganda's SME sector. The study by Dabla-Norris, Misch, Cleary, and Khwaja (2017) was not country specific.

The objective of this study was to establish the effect of tax administration and selected firm and owners' characteristics on firm performance in Uganda using the World Bank Enterprise Survey data. From the reviewed studies, it implies that there is need to understand the importance of tax compliance cost on SMEs' performance. This has policy implication regarding tax administration and tax rates for firm performance. In addition, the study contributes to literature since there is literature dearth about tax administration and tax rates on firm performance in Uganda.

Section 1.2 reviews the selected literature. The data and empirical strategy are described in section 2. Section 3 presents empirical findings and section 4 discusses the study findings, while section 5 presents the concluding remarks.

\subsection{Literature}

Uganda has structured business licensing to facilitate business start-ups. The Uganda Investment Authority was formed to ensure that all investors operate legally within Uganda. Furthermore, different sectors have unique laws governing licensing in those sectors. For instance, financial institutions are governed by the Financial Institutions Act (2004) with its subsequent amendments. In the same way, the mining sector is regulated by the Uganda Mining Act (2003). In addition, to facilitate an easy registration of patents and business undertakings, Uganda Registration Services Bureau (URBS) was formed by an Act of parliament in 1998. The URBS is responsible for civil registration, business registration, patents, intellectual property rights and other activities as required by law.

Besides registration, taxation and customs laws and regulations are in place. For instance, the Value Added Tax Act (1996) streamlines the operations of VAT domestically and at customs, the East African Customs Management Act (2004) together with the East African Customs Management (Amendment) Bill (2015) streamline the operations of customs activities at all East African border points. In addition, the Common External Tariff (CET) was established to guide on all duties for commodities imported from outside the East African Community. It is imperative to know that today, under the Tax Payer Registration Expansion Program (TREP), Small and Medium Size Enterprises (SMEs) are required to register for both business licensing and tax at one point. This implies that all SMEs leave the registration point with both the business operational license and the Tax Identification Number (TIN).

It is argued that, World over, formality is not a major goal for SMEs. They focus on expanding sales. Whereas tax and local authorities want SMEs to be registered and formalize their operations in order to collect tax revenue, SMEs want to remain informal to avoid paying taxes. It has been observed in Lima that obtaining a trading license does not guarantee increase in firm revenue (Alcazar, Andrade \& Jaramillo, 2010). Therefore, SMEs find no urgency in formalization. Moreover, obtaining a license involves costs in terms of monetary payments to local authorities and wasted time. Furthermore, trade is hampered by inconsistent collection of duties which influences traders to issue bribes to customs officials (United States Country Commercial Guides, 2017). Although the government of Uganda through Uganda Investment Authority (UIA) introduced onestop-center for registering businesses, the business registration period is an average of twenty six days (World 
Bank, 2016). This is still a long period of time. The United Nations Doing Business report (2017) indicates that the efficiency and quality of regulatory framework in Sub-Saharan Africa is still low at $56.5 \%$ and $36.7 \%$ on the Distance to Frontier (DTF) score. Therefore, the tax administrative system may be bypassed with irregular payments to favor some business operators at expense of others.

In addition, another conundrum originates from unrealistic tax rates. The high tax rates may also induce irregular payments because people feel that to survive in business, pay irregularly at below the rates. Furthermore, it can be argued that the tax rates imposed can hinder firm performance, for instance, the excise duty imposed on items can increase the selling price of an item, which may reduce the sales volume. The empirical findings of Gatsi, Gadzo and Kportorgbi, (2013) among Ghanaian manufacturing firms indicate that whenever tax burden increases, the firm's financial performance declines. Thus, whenever tax rates especially under the indirect tax regimes increase, there is expected reduction in firm clientele and sales hence more pressure on firm cash flows. Furthermore, in Malaysia, the Goods and Services Tax (GST) have slowed down the sales of the shipbuilding and ship repairing business (Sim, 2019).

Whereas tax/duty collection and business registration has been made easy through online platforms (online filing of returns and online business registration), business community is complaining about bribery and irregular payments (World Economic Forum, 2017). Moreover, public servants are corrupt (Enterprise Survey Uganda, 2013), this is coupled with bureaucratic hurdles which hamper efficiency (Investment Climate Statement, 2017; United States Commercial Guides, 2017).

It is based on the bribery, bureaucratic, high tax rates and inefficient ways of operation that the authors envisage that tax administration, tax rates and business licensing can hinder firm performance. Furthermore, delays in obtaining information wastes traders productive time, slows decision making in business hence low productivity and performance. For instance, innovation time is wasted, cash is used for bribes instead of funding the firm's liquid requirements.

Uganda like any other East African state has structured the customs procedures following the East African customs protocol. Before the protocol, each member state was following her own customs procedures. However, today, the common customs laws to all East African customs points were introduced. Laws such as; the East African Customs Management Act (2004) together with the East African Customs Management (Amendment) Bill (2015) regulate customs business at all East African border points. In addition, the Uganda National Bureau of Standard regulations (2015) are provided to guide the inspection of imports and exports to ensure compliance with international standards and to confirm the quality of imports. The Uganda National Bureau of Standards introduced a Pre-Export Verification of Conformity $(\mathrm{PVoC})$ following the World Trade Organisation's notification requirements and the Technical Barriers to Trade (TBT) article 5. The PVoC requires that all goods imported to Uganda are inspected for quality in the country of Origin. However, the clearance requirement challenges traders since they buy and import merchandise from open market rather than manufacturers (Musoke, 2012).

Furthermore, to ensure that customs regulations are implemented in a proper and efficient manner, new technology such as single customs territory has been introduced. The single customs territory enables traders to comply with customs procedures, and pay customs taxes at one entry point within a maximum of two days (World Bank, 2017; Nakaweesi, 2018). In addition, United Nations Doing Business report (2017) indicates that URA introduced one-stop center at Malaba in effort to expedite customs clearing processes. On top of these initiatives is the ASYCUDA World, the technology which is an enabler of efficient customs clearance process. Although the regulatory framework and technology has facilitated the reduction in hindrances at customs entry points, for instance, reduced time for customs processes and reduced time for client contact with the customs officers, the systems can only operate on internet. It is not prudent to assume that every place in Uganda has stable internet.

Important to state, most people in business community are not conversant with the customs regulations. They survive at the mercy of clearing agents who sometimes may not offer satisfactory advice, hence tax disputes between URA and the tax payer. It is also important to understand that although Uganda has a clear mechanism to address tax disputes between tax payers and URA provided in the Tax Procedure Code Act (2014), Uganda's commercial court is perceived to favor politically connected firms where such firms induce bribes to judges to delay cases or rule in their favor (United States Country Commercial Guides, 2017). In addition, the World Economic Forum (2016) indicates that border administration in Uganda is not transparent, has a lot of irregular payments and the clearance process is inefficient. Moreover, the main problem facing tax authorities in African countries in tax administration is corruption (Dube, 2014). 
The operations at customs guided by the customs regulations have led to significant improvement in efficiency at customs entry and exit points. Bogachkova, Usachyova and Usachyov (2019) argue that, a well simplified system of tax reporting of entrepreneurs improves SMEs business activities. However, there numerous challenges such as; the inadequate awareness of the regulations by business community, yet, tax awareness is positive and significantly related to tax compliance (Omondi \& Theuri, 2019). Unstable internet services, delays caused by customs officers and delays caused by disputes between URA and tax payers. The delays and impromptu bribes affect business performance. It can be argued that if time is lost at customs point, importers' sales will drop. It can further be argued that bribes, extra charges and time wastage during the appeal procedure can be a hindrance to firm sales, profitability or working capital.

\section{Methodology and Data}

\subsection{Methodology}

To establish the effect of tax administration and tax rates on SMEs' performance, the logit model was estimated. After obtaining results of the logit model, interviews were conducted to explain specifically; how tax administration affect the sales of a firm? How tax rates affect the sales of a firm? And how importers perceive the customs procedures at Uganda boarders? This is sequential explanatory research approach. The mixed methods ensure triangulation of methodologies (Johnson \& Onwuegbuzie, 2004).

Besides tax administration, other factors which can affect performance are; operating expenses such as rent, salaries, financial charges and utilities. The effect of tax administration on selected firm and industrial characteristics on SMEs' performance are examined by estimating the following model:

$$
\text { Perm }_{i}=\alpha_{0}+\alpha_{1} \text { Taxad }_{i}+\alpha_{2} \text { Firm }_{i}+\alpha_{3} \text { Industry }_{i}+\alpha_{4} \text { Owner }_{i}+\varepsilon_{i}
$$

From Equation 1, Perm $_{i}$ denotes firm performance. For this study, firm performance is measured by working capital, cumulative employment and sales volume. Taxad denotes tax administration, which is binary and is coded as ' 1 ' if tax administration has no effect and ' 0 ' if otherwise. Firm denotes firm characteristics which include firm size and firm age. Industrial factors include; firm location and type of business. Owner denotes whether firm owner is male or female and $\varepsilon$ is the normally distributed error term.

For qualitative interviews, purposive sampling was employed to select the customs officers and customs agents who are engaged in customs business. SME managers were included because they import goods and services. The interviews intended to explain the results obtained from the quantitative logit modelling. The sample size is twenty respondents and this is considered adequate (Creswell, 2013). The customs boarder points considered for the study are: Busia and Malaba in Eastern Uganda and Mutukula in Southern Uganda. The choice of these entry points is for their being busy with clearing imports.

Before conducting interviews, interviewees' consent was sought and each interview took a maximum of twenty minutes. The interviewers also assured the respondents that they were not under any threat.

Whereas the quantitative data was obtained from World Bank Enterprise survey for Uganda (2013) thus requiring no validity and reliability tests, an interview guide was subjected to peer review and debriefing, ensuring adequate sample size, transparency and credibility in handling data. Finally analysis for qualitative interviews was conducted through coding and creating themes.

\subsection{Data Description}

This study uses the 2013 WBES data for Uganda which was collected between January and August 2013. The survey employed stratified random sampling technique so as to: 1) get rid of biased estimates for the entire population; 2) get rid of biased estimates for different subdivisions of the population with a given degree of informed precision; 3 ) ensure that different sectors are well represented in the final sample; and 4) benefit from the precision associated with population estimates in stratified sampling as opposed to simple random sampling among others. The survey was based on a sampling frame obtained from Uganda Bureau of Statistics. In terms of stratification, the survey employed three levels of stratification that is region, size and industry. Specifically, in terms of the region, the survey was undertaken in Jinja (central Eastern Uganda), Kampala (City found in central Uganda), Lira (Northern Uganda), Mbale (Eastern Uganda), Mbarara (Western Uganda) and Wakiso (Central Uganda). In terms of size, the survey covered small, medium and large enterprises. Small enterprises comprised of firms with 5 to 19 employees, medium enterprises compromised of firms with 20 to 99 employees while large firms had 100+ employees. The data was collected from only formal (registered) companies with 5 or more employees. 
With regard to our study, we have a sample of 698 SMEs of which, 324 SMEs were surveyed in the manufacturing sector which included food, textiles, garments, tobacco, leather, wood, paper, publishing, printing, and recorded media, refined petroleum products, chemicals, plastics and rubber, non-metallic mineral products, basic metals, fabricated metal products, machinery and equipment, electronics, precision instruments, transport machines, furniture and recycling.

The key study variables used in the empirical analysis include firm age. Unlike other study Pervan, Pervan and Curak (2017) in Croatia food industry indicates that firm age has a significant negative relationship with firm performance. This study only examined the linear effect of age on firm performance. Furthermore, Coad, Daunnfeldt and Halvarsson (2017) established that new firms strive to grow in sales level, however, after some few years, growth loses momentum. However, the current study takes into account the nonlinear effect of age on firm performance.

Also, the study employs firm size following Perez-Quiros and Timmerman (2000) who contend that small firms have a lower return on stocks during recession compared to large firms. This implies that small firms face more liquidity problems compared to large firms. Furthermore, Capenter and Petersen (2002) in the study of 'is the growth of small firms constrained by internal financing?' concluded that the growth of small firms is constrained by internal financing. Implying that whenever small firms have constraints in liquidity, sales, market share, and assets level can be low.

In addition, this study employs firm location to examine firm performance following Holmes (1999) who argues that firms that locate in places of high population growth experience increased local production. He concluded that as population increases, a set of goods expand. Firms tend to locate where tax rates are lower compared to places of higher tax rates. This is basically because some tax rates affect business cash flows for instance excise duty. Fossen and Steiner (2014) established that the variation in elasticity of local business tax among Germany municipalities is -0.45 .

Gender of the owner is also used to examine firm performance following Coleman (2007). Women owned firms find it difficult to secure external capital which humpers their business growth compared to men (Coleman, 2007). De Mel, McKenzie and Woodruff (2009) established that men invest both the small and large grants while women only invest large grants. Men can earn more return by $6.5-14 \%$ while women do not get a return (De Mel et al., 2009).

\section{Results}

Table 1 provides the summary statistics for the key selected study variables. Firm performance is measured as a firm's total annual sales in the fiscal year prior to the survey divided by the number of permanent full time employees at the firm in the fiscal year prior to the survey. The mean sales is UGX 6,330 million. The minimum and maximum firm sales is UGX 400,000 and UGX 9, 7000 million respectively. Firm age defines the number of years a firm has been in existence. The mean age of the firms is 15 years to suggest that on average many of the firms are mid-aged. The youngest and oldest firm is 2 and 87 years old respectively. On average 31 percent of firms are managed by female managers. Export measures a firm's export status and it takes a value of ' 1 ' if a firm exports otherwise ' 0 '. One average 8 percent of firms engage in exports. Use of website and emails for business were coded as ' 1 ' and ' 0 ' otherwise. On average 18 percent of firms have own websites and 39 percent use email for business. On average 88 percent of firms are domestically owned, 4 percent are jointly owned, while 8 percent are foreign owned. 
Table 1. Summary statistics for the study variable

\begin{tabular}{lllllll}
\hline Variable & $\mathrm{N}$ & Mean & $\mathrm{Sd}$ & $\mathrm{Cv}$ & Min & Max \\
\hline Firm sales & 460 & $6.33 \mathrm{E}+09$ & $5.1 \mathrm{E}+10$ & 8.06 & 400000 & $9.75 \mathrm{E}+11$ \\
Female owner & 689 & 0.31 & 0.46 & 1.48 & 0 & 1 \\
Years of experience & 670 & 13.37 & 8.21 & 0.61 & 1 & 41 \\
Firm age & 646 & 15.17 & 9.9 & 0.65 & 2 & 87 \\
Exporter & 698 & 0.08 & 0.27 & 3.36 & 0 & 1 \\
Domestic ownership & 695 & 0.88 & 0.33 & 0.38 & 0 & 1 \\
Joint ownership & 695 & 0.04 & 0.2 & 4.88 & 0 & 1 \\
Foreign ownership & 695 & 0.08 & 0.28 & 3.32 & 0 & 1 \\
Access to credit & 606 & 0.61 & 0.49 & 0.8 & 0 & 1 \\
Medium firm & 698 & 0.33 & 0.47 & 1.43 & 0 & 1 \\
Use website & 692 & 0.21 & 0.41 & 1.96 & 0 & 1 \\
Use email & 691 & 0.39 & 0.49 & 1.25 & 0 & 1 \\
Tax rate & 693 & 0.61 & 0.49 & 0.8 & 0 & 1 \\
Tax admin & 696 & 0.56 & 0.5 & 0.88 & 0 & 1 \\
Customs & 686 & 0.46 & 0.5 & 1.08 & 0 & 1 \\
Training & 693 & 0.7 & 0.46 & 0.66 & 0 & 1 \\
Ltd company & 679 & 0.08 & 0.27 & 3.44 & 0 & 1 \\
Sole proprietor & 679 & 0.68 & 0.47 & 0.68 & 0 & 1 \\
Partnership & 679 & 0.24 & 0.43 & 1.78 & 0 & 1 \\
Licensed business & 696 & 0.49 & 0.5 & 1.01 & 0 & 1 \\
Registered at startup & 666 & 0.6 & 0.49 & 0.81 & 0 & 1 \\
Working capital & 662 & 5.91 & 13.82 & 2.34 & 0 & 100 \\
\hline Source: Authors tabutat
\end{tabular}

Source: Authors' tabulation from WBES (2013)

Table 2 presents the mean difference analysis for the study variables to explore the difference between male and female owned firms. It can be observed that age, access to credit and source of financing are key factors that differentiate between male and female owned firms.

Table 2. Summary statistics for differences between male and female firm owners

\begin{tabular}{lccccc}
\hline & & & \multicolumn{3}{c}{$99 \% * *, 95 \% * *, 90 \% *$ CI } \\
\cline { 3 - 5 } Variables & G1 $(0)$ & Mean1 & G2(Yes) & Mean2 & Mean Diff \\
\hline Firm sales & 301 & $8.200 \mathrm{e}+09$ & 154 & $2.700 \mathrm{e}+09$ & $5.500 \mathrm{e}+09$ \\
Male owner & 457 & 13.02 & 207 & 14.13 & -1.102 \\
Years of experience & 434 & 14.51 & 203 & 16.37 & $-1.867^{* *}$ \\
Firm age & 473 & 0.0820 & 216 & 0.0740 & 0.00800 \\
Domestic ownership & 471 & 0.877 & 216 & 0.894 & -0.0170 \\
Joint ownership & 471 & 0.0280 & 216 & 0.0560 & $-0.028^{*}$ \\
Foreign ownership & 471 & 0.0960 & 216 & 0.0510 & $0.045^{* *}$ \\
Access to credit & 413 & 0.579 & 187 & 0.679 & $-0.100^{* *}$ \\
Medium firm & 473 & 0.334 & 216 & 0.306 & 0.0280 \\
Use website & 469 & 0.179 & 215 & 0.251 & $-0.072^{* *}$ \\
Use email & 469 & 0.341 & 213 & 0.484 & $-0.142^{* * *}$ \\
Tax rate & 469 & 0.597 & 215 & 0.651 & -0.0540 \\
Tax admin & 472 & 0.544 & 215 & 0.614 & $-0.069^{*}$ \\
Customs & 464 & 0.459 & 213 & 0.460 & -0.00100 \\
Training & 471 & 0.724 & 213 & 0.667 & 0.0570 \\
Ltd company & 461 & 0.0560 & 212 & 0.118 & $-0.062^{* * *}$ \\
Sole proprietor & 461 & 0.748 & 212 & 0.557 & $0.192^{* * *}$ \\
Partnership & 461 & 0.195 & 212 & 0.325 & $-0.130^{* * *}$ \\
Licensed business & 472 & 0.479 & 216 & 0.528 & -0.0490 \\
Registered at startup & 450 & 0.609 & 207 & 0.580 & 0.0290 \\
Working capital & 453 & 5.113 & 204 & 7.838 & $-2.726^{* *}$ \\
\hline Source: Authors & & &
\end{tabular}

Source: Authors' tabulation from WBES (2013)

\subsection{Empirical Results}

From Table 3 while this article provides better understanding of the effect of tax administration taking into account tax rate on SME performance in Uganda (Model 1 and 2), for the $25^{\text {th }}$ percentile (low performance firms) and $75^{\text {th }}$ percentile. Note, that the $50^{\text {th }}$ percentile results are equivalent to the OLS results (Model 1). Therefore, the effect of tax administration on firm performance is examined taking into account firm and business 
environment characteristics. The use of quintile analysis in this article is to enable us to understand whether the relationship between tax administration and firm performance is uniform across different quintiles; as the sales of firms varies significant despite being the same size.

Table 3. Estimated impact of tax administration on firm performance

\begin{tabular}{|c|c|c|c|}
\hline \multirow[b]{2}{*}{ Variables } & \multirow[b]{2}{*}{$\begin{array}{c}\text { Model } 1 \\
\text { OLS (0.5) }\end{array}$} & \multicolumn{2}{|c|}{$99 \% * * *, 95 \% * *, \quad 90 \% * \mathrm{CI}$} \\
\hline & & $\begin{array}{c}\text { Model } 2 \\
0.25 \\
\end{array}$ & $\begin{array}{c}\text { Model 3 } \\
\mathbf{0 . 7 5} \\
\end{array}$ \\
\hline Tax administration not an obstacle & $\begin{array}{c}0.201 \\
(0.180)\end{array}$ & $\begin{array}{c}0.094 \\
(0.531)\end{array}$ & $\begin{array}{c}-0.311 \\
(0.102)\end{array}$ \\
\hline Tax rate not an obstacle & $\begin{array}{l}0.016^{*} \\
(0.077)\end{array}$ & $\begin{array}{l}0.028^{*} \\
(0.054)\end{array}$ & $\begin{array}{c}0.507^{* * *} * \\
(0.008)\end{array}$ \\
\hline Male owner & $\begin{array}{c}0.094 \\
(0.555)\end{array}$ & $\begin{array}{c}0.039 \\
(0.806)\end{array}$ & $\begin{array}{c}0.208 \\
(0.289)\end{array}$ \\
\hline Firm age & $\begin{array}{c}0.033 \\
(0.293)\end{array}$ & $\begin{array}{c}0.153 * * * \\
(0.000)\end{array}$ & $\begin{array}{c}0.103^{* * *} \\
(0.008)\end{array}$ \\
\hline Firm age squared & $\begin{array}{l}-0.037 \\
(0.657)\end{array}$ & $\begin{array}{c}-0.456^{* * * *} \\
(0.000)\end{array}$ & $\begin{array}{l}-0.185^{*} \\
(0.081)\end{array}$ \\
\hline Exporter & $\begin{array}{c}0.759 * * \\
(0.011)\end{array}$ & $\begin{array}{c}1.054 * * * \\
(0.001)\end{array}$ & $\begin{array}{c}0.389 \\
(0.293)\end{array}$ \\
\hline \multicolumn{4}{|l|}{ Firm ownership (RC: Domestic) } \\
\hline Both domestic and foreign & $\begin{array}{c}0.292 \\
(0.455)\end{array}$ & $\begin{array}{c}0.315 \\
(0.413)\end{array}$ & $\begin{array}{l}-0.143 \\
(0.765)\end{array}$ \\
\hline Foreign ownership & $\begin{array}{c}1.576 * * * \\
(0.000)\end{array}$ & $\begin{array}{c}1.034 * * * \\
(0.001)\end{array}$ & $\begin{array}{l}0.705^{*} \\
(0.060)\end{array}$ \\
\hline Access to credit & $\begin{array}{c}0.165 \\
(0.274)\end{array}$ & $\begin{array}{c}0.044 \\
(0.768)\end{array}$ & $\begin{array}{c}0.498 * * * \\
(0.007)\end{array}$ \\
\hline Medium firms & $\begin{array}{c}0.972 * * * \\
(0.000)\end{array}$ & $\begin{array}{c}0.480 * * * \\
(0.004)\end{array}$ & $\begin{array}{l}0.378^{*} \\
(0.069)\end{array}$ \\
\hline Firm uses website & $\begin{array}{c}0.666 * * * \\
(0.003)\end{array}$ & $\begin{array}{c}1.248 * * * \\
(0.000)\end{array}$ & $\begin{array}{c}1.172 * * * \\
(0.000)\end{array}$ \\
\hline Firm uses email & $\begin{array}{c}0.492 * * * \\
(0.009)\end{array}$ & $\begin{array}{c}0.533 * * * \\
(0.004)\end{array}$ & $\begin{array}{c}0.600 * * * \\
(0.009)\end{array}$ \\
\hline Customs & $\begin{array}{c}0.095 \\
(0.525)\end{array}$ & $\begin{array}{c}0.212 \\
(0.153)\end{array}$ & $\begin{array}{l}-0.128 \\
(0.486)\end{array}$ \\
\hline Training & $\begin{array}{c}-0.441 * * * \\
(0.007)\end{array}$ & $\begin{array}{c}-0.358 * * \\
(0.026)\end{array}$ & $\begin{array}{c}-0.412^{* *} \\
(0.039)\end{array}$ \\
\hline \multicolumn{4}{|c|}{ Firm legal status (RC: LTD Company) } \\
\hline Sole proprietor & $\begin{array}{c}-1.030 * * * \\
(0.000)\end{array}$ & $\begin{array}{c}-0.704 * * * \\
(0.006)\end{array}$ & $\begin{array}{c}-1.583 * * * \\
(0.000)\end{array}$ \\
\hline Partnership & $\begin{array}{l}-0.086 \\
(0.752)\end{array}$ & $\begin{array}{l}-0.238 \\
(0.376)\end{array}$ & $\begin{array}{l}-0.111 \\
(0.740)\end{array}$ \\
\hline Business licensed & $\begin{array}{l}-0.185 \\
(0.215)\end{array}$ & $\begin{array}{c}-0.291 * * \\
(0.048)\end{array}$ & $\begin{array}{l}-0.211 \\
(0.248)\end{array}$ \\
\hline Constant & $\begin{array}{c}18.20 * * * \\
(0.000)\end{array}$ & $\begin{array}{c}16.40 * * * \\
(0.000)\end{array}$ & $\begin{array}{c}19.32 * * * \\
(0.000)\end{array}$ \\
\hline $\begin{array}{l}\text { Observations } \\
\text { R-squared }\end{array}$ & $\begin{array}{c}369 \\
0.180\end{array}$ & $\begin{array}{c}367 \\
0.139\end{array}$ & $\begin{array}{c}367 \\
0.208\end{array}$ \\
\hline
\end{tabular}

Besides the quantitative modeling, qualitative interviews were conducted and data analysed for the purpose of explaining the quantitative results in table 3. The response rate was $95 \%$ and obtained from customs officers, customs agents and business community. The data was carefully edited, cleaned and well coded.

\section{Discussion of Findings}

The descriptive statistics from Table 1 indicate that on average, $18 \%$ of firms use websites and $39 \%$ of firms use emails. This implies that all other firms find difficulties in communicating with URA since URA commonly uses emails in effecting communication with the tax payers. Besides, firms which do not use emails and websites find it difficult to access relevant information on URA website. The findings further imply that many firms in Uganda may not be having internet connection. This negatively affects the timely delivery of information from URA.

In addition, from Table 3 model 1, tax administration is positive and insignificantly related to firm performance in the 0.25 and 0.5 quintiles. This is to say, tax administration procedures are not much of an obstacle to firm sales. However, in the 0.75 quintile, the relationship between tax administration and firm performance is 
negative and insignificant. Implying that tax administration procedures mildly obstruct firm sales as level of sales increases. The findings concur with, Akinboade (2014) who established that bribes to tax regulators negatively impact on business trading volumes. Furthermore, the study findings concur with Dabla-Norris et. al, (2017) who established that a sturdier tax administration has a positive effect on productivity of small and young firms. Also, the corruption which is in African tax administration bodies cited by Dube (2014) does not affect firm performance. Although Uganda Revenue Authority (URA) has a research unit, some traders are of a view that the research component is lacking thus impacting on tax administration component of the revenue authority. For instance, respondent 4 operating a motor spare shop asserts, 'tax officials do not conduct enough research before a decision is made. So they end up making a lot of mistakes that impact on our sales. Sales revenue differ among importers because of difference in tax rates charged to them'.

Despite the fact that URA has improved the tax administration system by providing information on its website and printing tax education materials, some business people still believe that the system is not transparent enough. For instance; respondent 6, operating a hardware store asserts, 'tax policies and tax rates especially on consumables are not clear, so we charged taxes we don't understand as traders, we push the burden to consumers which affects our sales'. The responses from interviewees 7,9,10 and 11 concur with interviewee 6 that tax administration procedures are not effective enough. Also, tax administration procedures frequently change, so traders are always not comfortable with the system.

The study findings indicate that tax rates are positive and significantly related to firm performance. This implies that tax rates are not an obstacle to firm performance. The effect is much higher at 0.75 quintile. The higher the level of sales, the lesser the tax rates become an obstacle. This is to concur with Mawejje and Sebudde (2018) who did not find significant relationship between taxation and firm performance.

To concur with results in table 3, it was observed that a firm that sells goods where government regulations or policy mandates everyone to consume its products, the firm's sales may not be affected by increase in tax rates or sales can be directly proportional to tax rates. This is adduced by respondent 7 , a firm transacting in motor cycle spares and 14 who avows, "If tax on imports increase, prices on the final product will increase. However, for firms importing helmets, their sales may not be affected by increase in tax rates or sales may increase since its government policy that everyone riding must wear helmets'.

Contrary to the findings in table 3 above, respondent 5 , an importer of new clothes, respondent 8 , selling computers and office equipment, respondent 11 who transacts second hand clothes and respondent 12 who transacts in mobile telephone accessories, observe, "higher tax rates increases prices and leads to reduction in business sales. This is because, consumers have less amount to spend'. But, the difference in argument is created by government interference in some of the sectors.

Furthermore, the study's findings are in agreement with Alcazar et. al, (2010) who assert that business licensing does not guarantee increased revenue. At the lowest level of sales, the 0.25 quintile, business licensing significantly reduces firm sales. This is an indicator that firms may choose to remain informal, after all, an authority's license does not translate in more revenue. Results also indicate that the relationship between customs and trade regulations and firm sales is insignificant. Implying that customs and trade regulations are not much of an obstacle to firms' performance in Uganda.

The responses obtained indicate, however, that importers do not fully understand the customs procedures and regulations. For instance, respondents 16 and 18 said, 'customs officers are not transparent, they do not easily define taxes payable by importers at entry point'. Some importers have bad experience with customs officers for instance, respondent 12 avows that customs officers are too arrogant to give important information about customs procedures. The negative remarks are made despite the fact that respondent 1 , a customs agent and respondent 19, a customs officer at Malaba emphasise that they explain the procedures to importers. Illiteracy was also pointed out by respondent 5 as a factor which hinders business community to understand the customs procedures. Eventually, a simple process becomes a time wasting event. The experience at customs point indicates the weakness in tax awareness process. It must be understood that a good tax awareness system improves tax compliance (Omondi \& Theuri, 2019).

The study findings imply that, the time wastage, costs for delayed decisions and tax compliance costs as a result of inefficiencies in Uganda's tax administration does not entirely affect firm sales. Although the quality of tax regulatory framework in Sub-Saharan Africa is below the Distance to Frontier Score (Nations Doing Business report, 2017), findings indicate that this position does not entirely affect firm sales. This position is similar to that of Matarirano et al; (2019) in South Africa who established that internal tax compliance costs are positive and significantly related to firm performance. 
Furthermore, the results in table 3 indicate a significant positive relationship between tax rates and firm sales. The study findings differ from that of Gatsi et, al; (2013), who established that when tax burden increases, the firm's financial performance declines. The bureaucratic huddles are cited in Uganda's tax administration system (Investment Climate Statement, 2017; United States Commercial guides, 2017), however, this does not inversely affect firm sales. The study findings also show that the inability for tax payers to understand customs and trade regulations is not an obstacle to firm sales.

\section{Conclusion}

This article examine the impact of tax administration on SMEs performance in Uganda taking into account the entrepreneur's characteristics and business environment using data drawn from World Bank Enterprise Survey for Uganda (2013). The qualitative interviews were conducted for the purpose of explaining the numeric from the logit model. The analysis employs both descriptive and estimation of quintile regression model. The results reveal that tax administration is not an obstacle to SME performance but the results are insignificant. Tax rates are not an obstacle to SMEs performance and the results are significant. Also, access to credit is significant in the 0.75 quintile, training has a significant inverse relationship with SMEs performance, male ownership is insignificant at all levels and age of the firm significantly increases SMEs' performance at the .25 and .75 quintiles. Other household and business environmental factors that are associated with low SME performance include legal status of the firm and domestic ownership. The study findings suggest that other factors perhaps significantly contribute to the poor performance of SMEs in Uganda but not necessarily tax rates and tax administration procedures.

The findings suggest that efforts for financial access interventions, such as promoting credit guarantee for SMEs with formal financial institutions, can have a substantial impact on SME performance. Of course, not every SME can apply for credit due to unfavorable business environment and entrepreneurs' objectives. Such constraints should be taken into account when formulating policy, targeting financial access interventions in both rural and urban areas where there is difference in access to formal financial institutions. In addition, there is need for raising awareness of the advantages of tax administration on SMEs and the benefits of staying away from informal business practices, particularly the young SMEs which always operate with no formal business licenses should be encouraged to register their businesses. Behavioral change interventions are nevertheless no substantial panacea and should be complemented by promotion and providing tax training to the entrepreneurs in the country. In the meantime, policy effort should concentrate on promoting tax compliance behavioral strategies and promoting business licensing, with the extreme case of eliminating informal businesses that are hard to tax. Thus, the combination of strategies targeting tax administration and access to credit are a promising path for policy makers.

\section{Study Contribution}

Whereas Dabla-Norris, Misch, Cleary, and Khwaja (2017) employed difference in difference in case of small firms and difference in difference in case of young firms, this study used logit and quintile estimation techniques to arrive at results. By way of literature, the higher the level of sales, the lesser an obstacle tax rates become to SMEs.

\section{Acknowledgement}

The authors wish to express their gratitude to Makerere University and SIDA for providing the necessary support and resources to facilitate the completion of this research.

\section{References}

Akinboade, A. O. (2014). Regulation, SMEs' growth and performance in Cameroon's central and littoral provinces' manufacturing and retail sectors. African Development Review, 26(4), 597-609. https://doi.org/10.1111/1467-8268.12116

Alcazar, L., Andrade, R., \& Jaramillo, M. (2010). Panel/tracer study on the impact of business facilitation processes on enterprises and identification of priorities for future business enabling environment projects in Lima, Peru - Report 5: impact evaluation after the third round. Report of the International Finance Corporation. World Bank Group, Washington, Dc, Processed.

Bogachkova, L. Y., Usachyova, N. Y., \& Usachyov, A. A. (2019). Increasing business activity of Russian SMEs: problems and solutions illustrated with the example of Volgograd region. Paper presented at the Second International Scientific Conference on 'Competitive, Sustainable and Safe Development of Regional Economy’, Atlantic Press. https://doi.org/10.2991/cssdre-19.2019.127 
Bosma, N., Van Praag, M., \& Wit, G. (2002). Entrepreneurial venture performance and initial capital constraints; an empirical analysis. Netherlands, Zoetermeer (Business \& policy research). Retrieved January 25, 2018, from www.eim.nl/smes-and-entrepreneurship/

Carpenter, E. R., \& Petersen, B. C. (2002). Is the growth of small firms constrained by internal financing? The review of Economics and Statistics, 84(2). 298-309. https://doi.org/10.1162/003465302317411541

Coad, A., Daunfeldt, S. O., \& Halvarsson, D. (2017). Bursting into life: Firm growth and growth persistence by age. Journal of Small Business Economics, 50(1), 55-75. https://doi.org/10.1007/s11187-017-9872-8

Coleman, S. (2007). The role of human capital and financial capital in the profitability and growth of women-owned small firms. Journal of Small Business Management, 45(3), 303-319. https://doi.org/10.1111/j.1540-627X.2007.00214.x

Creswell, J. W. (2013). Qualitative inquiry and research design choosing among five approaches (3rd ed.). New Dehli. Sage.

Dabla-Norris, E., Misch, F., Cleary, D., \& Khwaja, M. (2017). Tax administration and firm performance: New data and evidence for emerging market and developing economies. International Monetary Fund working paper, (WP/17/95). https://doi.org/10.5089/9781475595147.001

De Mel, S., McKenzie, D., \& Woodruff, C. (2009). Are women more credit constrained? Experimental evidence on Gender and Microenterprise returns. American Economic Journal of Applied Economics, 1(3), 1-32. https://doi.org/10.1257/app.1.3.1

Dube, G. (2014). Informal sector tax administration in Zimbabwe. Journal of Public Administration and Development, 34(2014), 48-62. https://doi.org/10.1002/pad.1673

Ecuru, J., \& Kawooya, D. (2015). Effective innovation policies for development: Uganda. Retrieved January 18, 2018, from http://www.wipo.int/edocs/pubdocs/en/wipo_pub_gii_2015-chapter11.pdf

Fossen, F. M., \& Steiner, V. (2014). The tax rate elasticity and business profit. Diskussionsbeitrage, 28. University of Berlin School of Business and Economics. https://doi.org/10.2139/ssrn.2526806

Gatsi, G. J., Gadzo, G. S., \& Kportorgbi, H. K. (2013). The effect of corporate income tax on financial performance of listed manufacturing firms in Ghana. Research Journal of Finance and Accounting, 4(15), 118-124.

Godin, M., \& Hindriks, J. (2015). A review of critical issues on tax design and tax administration in a global economy and developing countries. Retrieved January 23, 2018, from https://cdn.uclouvain.be/public/Exports\%20reddot/core/documents/coredp2015_28web.pdf

Holmes, J. T. (1999). Scale of local production and city size. The American Economic Review, 89(2), 317-320. https://doi.org/10.1257/aer.89.2.317

Investment Climate Statement. (2016). Tax administration and regulatory framework in Uganda. Retrieved August 8, 2018, from https://www.state.gov/e/eb/rls/othr/ics/investmentclimatestatements/\#wrapper

Johnson, B. K., \& Onwuegbuzie, A. J. (2004). Mixed methods research: A research paradigm whose time has come. American Education Research Association, 33(7), 14-26. https://doi.org/10.3102/0013189X033007014

Kangave, J., Nakato, S., Waiswa, R., \& Zzimbe, L. P. (2016). Boosting revenue collection through taxing high net worth individuals: The case of Uganda. UKAID working paper. https://doi.org/10.2139/ssrn.2776590

Kato, M. (2017). Procedures and challenges in tax collection. Retrieved January 17, 2018, from https://www.africa-uganda-business-travel-guide.com/procedures-and-challanges-in-tax-collection.html

Kintu, I. (2017). The relationship between core values and entrepreneurial performance: A study of SMEs in the informal economy of Uganda's central region (PHD Thesis, University of Witwatersrand, Johannesburg South Africa).

Matarirano, O., Chiloane-Tsoka, G. E., \& Makina, D. (2019). Tax compliance costs and small business performance: evidence from the South African construction industry. South African Journal of Business Management, 50(1), 1-9. https://doi.org/10.4102/sajbm.v50i1.336

Mawejje, J., \& Sebudde, K. R. (2018). Constraints or complaints? Business climate and firm performance perceptions in Uganda. The Journal of Development Studies.

https://doi.org/10.1080/00220388.2018.1502878 
Musoke, G. (2012). Evaluate impact of Pre-Export Verification Conformity. Retrieved from http://www.monitor.co.ug/Business/Prosper/Evaluate-impact-of-Pre-Export-Verification-of-Conformity/688 616-1640836-dgdjcl/index.html

Nakaweesi, D. (2018). Exports to ease as Uganda starts using single customs territory. Retrieved from http://www.monitor.co.ug/Business/Markets/Exports-ease-Uganda-starts-single-customs-territory/688606-4 350392-34bgs3z/index.html

Omondi, J. A., \& Theuri, J. M. (2019). Effect of tax payer awareness and compliance costs on tax compliance among small scale traders in Nakuru town, Kenya. International Academic Journal of Economics and Finance, 3(3), 279-295.

Perez-Quiros, G., \& Timmerman, A. (2000). Firm and cyclical variations in stock returns. The Journal of Finance, 55(3), 1229-1262. https://doi.org/10.1111/0022-1082.00246

Pervan, M., Pervan, I., \& Curak, M. (2017). The influence of age on firm performance: Evidence from the Croatian food industry. Journal of Eastern Europe Research in Business and Economics. https://doi.org/10.5171/2017.618681

Price Water House Coopers. (2016). Tax watch. Retrieved January 16, 2018, from https://www.pwc.com/ug/en/assets/pdf/tax-watch-2016.pdf

Sim, L. S. (2019). Impact of Goods and Services Tax (GST) on shipbuilding and ship repairs industry in Sarawak. International Academic Research Journal of Social Science, 5(1), 23-34.

Uganda Bureau of Statistics. (2018). Time to cross and traders' perception baseline survey. Retrieved from https://www.ubos.org/wp-content/uploads/publications/11_2018GLTFP-REPORT-PERCEPTION_AND_TI ME_TO_CROSS-2018-_final.pdf

Uganda Revenue Authority's Annual Report. (2015/2016). Retrieved January 16, 2018, from https://www.ura.go.ug/Resources/webuploads/GNRART/Annual\%20Report\%20FY\%2015-16.pdf

United States Country Commercial Guides. (2017). Doing Business in Uganda. United States Department of Commerce, International Trade Administration.

World Bank. (2016). Doing Business in Uganda. Retrieved August 8, 2018, from http://www.doingbusiness.org/

World Bank. (2017). Doing Business in Uganda. Retrieved August 8, 2018, from http://www.doingbusiness.org/

World Economic Forum. (2016). The Global Enabling Trade Report. Retrieved August 8, 2018, from http://reports.weforum.org/global-enabling-trade-report-2016/

World Economic Forum. (2017). Global Competitive Report. Retrieved August 8, 2018, from https://www.weforum.org/reports/the-global-competitiveness-report-2016-2017-1

Yu, M. C. (2013). The influence of high performance human resource practices on entrepreneurial performance: the perspective of entrepreneurial theory. International Journal of Organisational Innovation, 6(1).

\section{Copyrights}

Copyright for this article is retained by the author(s), with first publication rights granted to the journal.

This is an open-access article distributed under the terms and conditions of the Creative Commons Attribution license (http://creativecommons.org/licenses/by/4.0/). 